\title{
Statelessness and forced displacement in the era of post-globalization: A Case Study on Rohingya Crisis
}

\author{
Athulya $^{1}$
}

\begin{abstract}
The issue of forced displacement and human rights violations is a global concern and a major challenge against development. The Rohingyas are the ethnic Muslim minority group of the Rakhine state of Myanmar. Ethnicity and identity conflict over Rohingyas has been historical. They are considered to be stateless persons without any legal and political rights, neither accepted by state of Myanmar nor Bangladesh. The denial of their citizenship has resulted not only in denial of their basic rights but also in serious human rights violations such as genocide, forced labour, sexual violence etc. They have been discriminated from the mainstream economic development of the country with lack of access to basic rights for individual's development. The discriminatory practices towards this community make a strong case for reassessing the international response to stateless refugees. This study will try to find how issue of forced displacement is not only denial of basic human right but also humanitarian crisis globally. It will discuss the need for long term development policy towards displaced communities by framing systematic international refugee system.
\end{abstract}

Key words: Statelessness, Citizenship, Human rights violations, Global Humanitarian crisis, Genocide, Forced displacement, Ethnic- cleansing

${ }^{1}$ Dr. Athulya is an Assistant Professor- Political Science, Reva University, Yelhankha, Bengaluru64, India 


\section{Statelessness and forced displacement in the era of post-globalization: A Case Study on Rohingya Crisis}

\section{Introduction}

Over 60 million estimated refugees and internally displaced people are there in the world (Harild, 2016). The average speed of displacement is increasing and is likely to increase even further. These displaced people results in social, economic, fiscal challenges not only host countries but also slows down economic growth of a country. Moreover it also creates an internal instability and conflict in a country. Only a few of the displaced people are able to avail themselves with basic necessities and identity. As resettlement especially in developing countries are more expensive, often voluntary return of refugees are restricted due to internal conflict, instability and underdevelopment. This movement is blocked by countries through following the policy restrictions like disintegration, de-naturalization and religious extremism.

As in case of Rohingya a Muslim ethnic minority of Rakhine state of Myanmar, has been historically as well as religiously internally and globally displaced community. The issue over their ethnicity and identity has resulted them to be the most persecuted people in the world, with the denial of basic rights required for a full development of an individual (for e.g., freedom to movement and employment). Moreover the increasing human rights violations against Rohingya as refugees have resulted in mass displacement and global threat to peace and security. It is not only seen as a humanitarian issue but also development issue by the host countries. As this mass population is seen as internal threat to economy, as opportunities and employment of a country is encroached by these illegal migrants denying the opportunities of the citizens of those countries.

Especially the country Bangladesh though provides refuge to a large population, sees Rohingya refugees as huge problem. As a poor country with political instability, infrastructure bottlenecks, bureaucratic corruption and natural calamities, only manage with the international aid and support. The issue over their identity has been historical where the Myanmar government considers them to be Bangladeshi settlers while Bangladesh refuses its claims and identifies them to be original inhabitants of Myanmar. Thus Bangladesh though provides refuge to over 1miilion but rejects to 
provide any legal claim over its territory. Perhaps it has resulted in human rights issues and violence against these refugees by Bangladeshi's over their encroachment of land and resources by blocking the development of Bangladesh's economy and posing a challenge to its progress.

Thus an increasing population of this displaced groups though gets a place to survive, they get intermingled with local communities of the host country but, largely lack any basic services and are also excluded from the formal job market on par with the local communities, thus the needs of the displaced and host communities are that of developmental at first. Moreover not only the denial of these basic rights or human capital but also violations of these rights as in case of Rohingya has led to severe humanitarian as well as human development crisis.

\section{Ethnic Conflict over Rohingya}

Ethnicity as a term is conditioned by various affinities such as race, nation, culture, customs, beliefs and languages. It is also based on socio-political interactions with other ethnic communities which often results in friction between communities sufficed by religious and ideological practices. While ethnic conflict refers to condition of tension and collision between two or more than two ethnic groups.

The various causes for ethnic conflict can be Primordialism which argues that people's ethnic and religious identities have deep social, historical and genetic foundations and that creates a separate psychology, culture and values within their ethnic and kinship surroundings. Even human security, basic needs and survival motivation comes from these internal and subjective forces [Rahman, 2015]. The most often reason is the rise of anarchism that take-off statehood of some minorities resulting in organized violence against the nationalist groups dominated by repressive state. According to Azar and Burton (1986) "the move to violence begins with the denial of separate identities, the absence of security for the minorities and absence of clear participation of these minorities". Also lack of trust between each other especially in a plural state triggers minor ethnic groups to involve in conflict. The groups always disclose suspect and mistrust behavior and the strong ethnic group always oppress them backed by the state. 
Myanmar is predominantly occupied by Burmese population by 68 percent of its total population and has been facing ethnic conflict ever since its independence in 1948. It is divided into states and regions, of which states are inhabited by Burmese and states dominated by ethnic minority groups. Even most of the states are named after that ethnic group who inhabit there. Until British annexation of Burma as an Indian province in 1886 the country never exist united (Abiru, 2018). There were several nationalities and groups encompassing within a single geographical boundary. Almost all minorities faced challenges against Buddhist majority but the most severe challenge was and is faced by Rohingya. Among the 135 officially recognised ethnic minorities granted with certain rights in Myanmar, the Rohingya were excluded and unrecognized by the government. This rendered Rohingya Stateless under the 1982 Citizenship Act, creating the world's largest minority. During the eve of its independence Major General Aung Sun, the Burmese Independence icon, persuaded the ethnic minorities such as Arakanese, Shan, Chin, Kachin to sign the 'Panglong Agreement' which promised exclusive autonomy for each ethnic groups. Accordingly, the Union of Burma and Shan, Kachin, Chin minority groups signed the agreement, but the successive government which came into power after independence failed to enforce the Panglong Agreement. The rise of Communist Party of Burma (CPB) and some Arakanese group like the Karen National Union also took up arms against since then there have been continuous armed conflicts and civil uprising in Myanmar (Abiru, 2018). As a result the government lost trust in non- Burmese ethnic groups and thus insurgency broke out paralyzing the government.

Ethnic and Communist insurgencies aided by People's Republic of China threatened the very existence of Burma as a united entity. The unwieldy political coalition and confused political situation enabled General Ne Win to take over power in 1962 to promise to safeguard integrity of Burma. At present Rohingya are denied of their rights compelling them to flee from Myanmar which is academically termed to as 'Ethnic Cleansing' carried out through process of persecution such as arson, mass killing, torture, rape etc.

\section{Myanmar's Political Turmoil and Identity Crisis of Rohingya}

The Military regime ruled almost for half a century in Burma, The military played a key role in politics of Myanmar right after its independence and remained until 2010. But it largely remained partial in dealing with the common people and they also adopted an anti-approach against 
Rohingya. They also followed staunch nationalist policies and Theravada Buddhism to prolong their regime, largely discriminating the minorities especially, the Rohingya. While on the other hand in some cases to consolidate their long term political strategy they have used Rohingya as scapegoats. Since some of the dissidents of ethnic Burman majority do not consider Rohingya as inhabitants of Myanmar.

It was the enactment of Citizenship Law of 1982 under the leadership of General Ne Win (19621988) first put Rohingya into territorial identity crisis. His government under Burmese Socialist Party adopted a hardcore stance towards minorities he expelled the Muslims from the army and at same time enacted 1974 Emergency Immigration Act that stripped the status of citizenship of Rohingya which made them foreigners in their own homeland prompting attempts to reform the Mujahidin Movement (Hariharan, 2018). The Citizenship Law refused to recognize Rohingya as its citizen without proper assessment denying their both claims of residency as well as of indigenous citizenship. Thus it is racism and religious prejudice which does not recognize them as its citizens.

The military also led several operations against Rohingya in the pretext of eliminating militant Rohingya who attack government institutions such as police stations. During 1978 'Operation Dragon King' or the Operation Naga Min which aimed at driving out Rohingya and declare as "foreigners" as well as to arrest leaders of Rohingya Patriotic Front (RPF) ${ }^{2}$ operating from Bangladesh (Hariharan, 2018). However the operation went beyond the issue of security and defense and acted against immigration. It led to first massive outflow of Rohingya to Bangladesh in fear of mass killing and torture resulting in huge political and economic turmoil inside and outside the country. From 1988-2011 the military regime encouraged conversion of ethnic minorities 'often by force' as a part of assimilation strategy by Buddhist nationalist. This also gave rise to Buddhist extremist movements like $\mathrm{Ma} B a T h a^{3}$ by Buddhist monk.

Later in 1982 as mentioned earlier, the Burma Citizenship Law was passed identifying 135 ethnicities entitled to citizenship excluding Rohingya and considering them as 'foreigners' but in

\footnotetext{
${ }^{2}$ Rohingya Patriotic Front (RPF): A political organisation headquartered in Cox Bazar, Bangladesh. Also a small insurgent army active in Rakhine state, Myanmar with a goal to create an autonomous Muslim zone for Rohingya. ${ }^{3} \mathrm{Ma} \mathrm{Ba}$ Tha: The patriotic association if Myanmar, translated as association and organisation for protection of race and religion, committee for protection of nationality and religion is an ultra-nationalist Buddhist organisation.
} 
reality as stateless. This new law provided certain categories of identification of citizenship: the first category of genuine citizens, who majorly belonged to eight ethnic groups since 1823(first Anglo Burmese war), second category included associate citizens, who got citizenship through 1948 union citizenship act and final category of naturalized citizen, who had naturalized after the suspension of 1948 law in 1950. However Rohingya did not fall into any of these categories, instead of National Registration Certification (NRC) they were provided with Foreigners Registration Certificate (FRC). Since NRC is considered pathway to basic access to political (voting) and economic (work and education) rights. The Rohingya were not even considered Arakanese Muslims but as illegal Bengali Muslims (Ventura, 2014). This resulted in trigger among Rohingya to establish contact with Muslim extremist groups and formed Rohingya Solidarity Organisation which developed contacts with terrorist groups like Al-Qaeda.

\section{Religious Extremism}

The Religious Extremism started with the issue of Muslim marginalization and persecution which continues to even present day. Growing Buddhist extremism where often the Buddhist religious leaders even under the colonial rule adopted violence and exclusion towards Rohingya has resulted in militancy among them. This hostility has elicited a growing response from foreign Islamists groups like Al Qaeda and other Jihadists movements are at present using their own narrative of Muslim persecution. The portrayal of Rohingya as Islamist terrorist has deep roots a decade before of political transition in Myanmar has been claimed of having two defunct groups, the Rohingya Solidarity Organisation ${ }^{4}$ and the Arakan Rohingya National Organisation ${ }^{5}$ had largely believed to have received training from Al-Qaeda operatives that Rohingya groups tried to establish connection with Burmese ethnic insurgent groups (Allchin, 2017). But there are also claims that the Rohingya have no terrorist connections as such, they are only a group that claims for its rights and not a terrorist group.

\footnotetext{
${ }^{4}$ Rohingya Solidarity Organization (RSO): A political organisation founded in 1982, with an ideology of Islamic nationalism of Rohingya. Formerly was a militant organisation formed under large scale military operation conducted by Myanmar armed forces later became defunct.

${ }^{5}$ Arkan Rohingya National Organisation (ARNO): A Rohingya political organisation based in London, UK. It had operated as an insurgent army, one among few representative of Rohingya people.
} 
However from 1988-1990 Myanmar's first ever multi-party elections led to an end to military rule. Aung San Su Kyi's National League for Democracy (NLD) which struggled for democratic rule creating international furore. The political turmoil between military junta who established (SLORC or State Law and Order Restoration Council) and democratic regime, leading to suppression of democratic activists by imprisonment and even house arrest until 2010, of which Muslims along with Rohingya supported this party to establish democracy. However Union Solidarity and Development Party formed the government and established many structural democratic changes in Myanmar.

In 1991, SLORC carried on another operation called Pyi Thaya Operation (Operation of Clean and Beautiful) which forced Rohingya to give up their lands, work in constructed projects with little or no wages, even forced to relocate without any compensation. The Buddhist was encouraged to migrate to Arakan by providing surplus land to them. Thus Rohingya became the victims already to Buddhist Arakanese but, the military also.

However Aung San Su kyi has failed to uphold the expectations on Rohingya issue. She denied the accusations on Army of massive ethnic cleansing and demanded for solid evidences against those allegations. However the government of Myanmar till date has denied UN agencies, International NGOs and the Press to visit Rakhine state although, allowing free coverage Media under recommendations of Kofi Annan Commission which reported eye witnessing accounts of atrocities by the Myanmar troops and Buddhist villagers (Hariharan, 2018). Though Myanmar and Bangladesh government agreed for voluntary repatriation of refugees but still, refugees continues to fear the conditions are not secure in Rakhine state to return. Media reports from Myanmar indicate army assisting to create Rohingya free buffer zones in the areas where Rohingya had lived to settle other Rakhine people. Thus evidently Myanmar is not implementing the agreement with Bangladesh on repatriation both letter and spirit (Hariharan, 2018).

Since only a small part of refugee agreed to return to Arakan as part of MOU between Bangladesh and Myanmar, the Rohingya were only provided with temporary resident certificate or white cards, thus not represent Rohingya as their legal citizens. Also denial to the issuance of birth certificates for Rohingya children, limitation of children, restriction on marriage (Ventura, 2014). 
It was the systematic and deliberative discrimination carried out in the name of religious fundamentalism against the minorities of the state. They used the concept of Buddhist identity as the basis for citizenship so as to deny the rights of minorities. Thus they used an easily ethnically identifiable group to victimize and exclude from the non- Burmese population who are Rohingya. Rohingya were used as tool for discrimination against ethnicity and identity.

\section{Deprivation of Nationality and Use of Force}

Since the military rule, Myanmar has been practicing forced expulsion of Rohingya population on large scale volume. The Military Operations such as Operation Nagami in 1978 which confirmed citizenship and issued identity cards ending Rohingya with no legitimate recognition ultimately, leading to a large scale displacement of Rohingya into Bangladesh. Thereafter in the process of illegalization aimed to impose serious bodily and mental harm to eventually destroy the Rohingya as a group.

Thereafter, Citizenship Law of 1982 that strictly removed Rohingya the full access to citizenship. This result in the internal displacement of Rohingya and was forced to flee the country as government started confiscating their lands (Gamez, 2017). Thus the Rohingya could not be categorized as first class citizens of Myanmar due to their native exclusion in which they failed to prove their presence prior to British rule due to various reasons such as lack of written records and even government unwillingness to register them. Ultimately Rohingya not only denied their basic rights but also received mistreatments and threats to human security. The 1982 citizenship law imposed restrictions on other minorities too but the degree of restrictions that Rohingya faced was different experienced for decades.

The Statelessness created by the 1982 Citizenship Law, has affected Rohingya's lives profoundly they are deprived of basic living conditions. They have become unwanted in their own land they are also unwelcomed by the places where they took refuge. The countries like Bangladesh and Thailand started taking coercive means against Rohingya. They adopted several methods like detention, forced repatriation, imprisonment, forced expulsion, torture etc (Ventura, 2014). 
As Myanmar is a party to Genocide Convention so there is a mandatory obligation for Myanmar to prevent and punish individuals responsible for the crime of Genocide. The following acts were included in Article 2 of Convention on Genocide, and these are: "killing members of the group, causing serious mental or bodily harm, deliberately inflicting conditions of life to bring about physical destruction in whole or in part". Thus the mental and physical harm of Rohingyas is closely linked to destruction of a culture and identity of a targeted group (Gamez, 2017).

\section{Forced Labor}

The mass displacement of Rohingya was the result of the harsh persecution omitted Burmese authority. During the military operation between1991-1992, rumors of forced labor, forced relocation, rape and killing at the hands of Burmese military was widespread. Nevertheless even testimonies from those who escaped and experienced these ill treatments were verified. Some villages in Myanmar like Buthidaung and Maungdaw witnessed how armies entered and occupied the areas, closed their mosques, seized local livestock, crops, expelled villagers from their homes and properties, and even forced them to work voluntarily for the military. Some of them even forced to build new villages for the non-Muslim Rakhine (Ventura, 2014).

International Labor Organisation indeed monitored carefully ongoing practices of forced labor in Myanmar and also set up a commission of inquiry to examine and scrutinize the Burmese implementation of the 1930 Forced Labor Convention which showed that Burma's failure in implementing the convention with continuing systemic use of force labor and reluctance and lack of effort by the Burmese authority to comply and follow the results of the inquiry (Ibid).

The establishment of Nat-Sat kut-Kwey Ye ${ }^{6}$ (Burmese border security force) their presence in the northern Rakhine state, resulted in increased number of 'voluntarily' work demand among Rohingya. Also implementation of government program in the outskirts and border areas was the "model villages" which particularly aimed to populate the less populated rural areas by transferring certain individuals and families in order to develop those areas. Most of the settlers were Burmese Buddhists there. The Rohingya were mainly affected by the project in two ways: firstly, the

\footnotetext{
${ }^{6}$ Nay-Sat Kut- Kwey Ye or NaSaKa: a border security force in north Rakhine, formed in 1992 . They are the main perpetrators of Human Rights Violations against Rohingya.
} 
Rohingya were obliged to give up the ownership of their properties to government such as lands and accept relocation. Secondly, the Rohingya were obliged to do voluntarily manual work to help the authorities for implementing the project. In case those who refused to work were detained and tortured by the military forces (Ventura, 2014).

\section{Rohingya as Refugees}

Rohingya from internally displaced persons to a refugee has been taken through a systemic and planned persecution by the home country in name of religious fundamentalism. Since 1970s, Rohingya have migrated across in a significant number more than officially estimated. The worst violence erupted in 2012, followed by an alleged case of rape of a Buddhist woman by Muslim men led to massive religious violence and state riots against Rohingya, forced 140,000 to internally displaced into the camps of Rakhine state (Shetty,Neranjan,2018). The latest mass exodus was to escape the communal violence and alleged abuses by the security forces. It was on 25 august 2017, deadly attack on Rohingya by ARSA militants on more than 30 militant posts (BBC, 2018).

The largest number of Rohingya have fled to an area known as Cox Bazaar, a district in Bangladesh after the troops backed by local Buddhist mobs attacked by burning their villages and killing civilians. Since then, it has caused almost 80,000 Rohingya to flee from underdeveloped and overpopulated refugees' camps of Myanmar to Bangladesh (Shetty, Nerajan, 2018). Amnesty International and Bangladesh government accused Burmese authorities laying landmine at borders used by fleeing Rohingya.

Thus Rohingya community continues to fight for their rights in legal proceeding due to their inability to be represented by the law. They live in such dire conditions, without proper health education and security conditions with the own government excluding them. They are forcing them to turn to international organizations for help while Myanmar's consistence rejection to international assistance and claim against human violations make the international agencies more difficult to interact with this population. Hence there is a critical need for government to represent this marginalised group that has been systematically revoked of its fundamental rights (Ibid).

In International Law, by theory it is essential that an asylum seeker should be provided the territory of the state in which he or she has to seek asylum. So the weak context of Southeast Asia where countries like Thailand, Indonesia, and Malaysia are not parties of the 1951 Refugee convention 
thus receiving Rohingya for these countries is hard because they lack a legal framework to grant protection and rights to asylum seekers. Hence this condition has caused Rohingya refugees to constantly live in fear of being detained and prosecuted also forced to move back to their own country where they are been attacked and persecuted. Undeniably, Rohingya refugee crisis is a pervasive condition as they are byproduct of military coup and massive Human Rights Violations. Rohingya face some of the major Human Rights concerns (Gamez, 2017).

\section{Sexual Abuse of Rohingya Women}

Sexual abuse is often used as tool to victimize the people who have almost lost everything in the process of displacement. It also dehumanizes the victims used as a weapon of war leading to further aggression. The UN Security Council had even passed a resolution on sexual abuse in UN Peacekeeping in 2016. The Rohingya community has also faced the problem of sexual abuse especially the Rohingya women who were raped by the military which often remained silent because of the reluctance of these women to disclose their sufferings. Rohingya are considered to be very conservative and religious, made them to be more challenging for those victims because they are discriminated and stigmatized. UN agencies on the ground, report an average of 60 births per day in the camps, many which were results of rapes (UN, 2018). They are forced to go through process of abortion within months without proper medical facilities and care. Moreover they are even not able to get married. The women often tend to not disclose their issues because of their religious values (Abiru, 2018). There is a lack of safe spaces for sanitation and privacy for women and girls in the overcrowded camps resulting in physical and psychological trauma especially to adolescent's girls there. But the authorities of Bangladesh refugee camps, the world's largest refugee camp often tend to reuse any such claims of sexual violence and abuses. It has been crammed because of the sheer number o people often leading to undesirable conditions. Also Rohingya women are profoundly traumatized even at their homeland according to the UN report on conflict related sexual violence, that charged the members of the Myanmar armed forces, at times jointly with locals used rape, gang rape, forced public nudity, abduction and other sexual violence attacks as a part of their strategy to drive out the Rohingya (UN, 2018).

The gender based violence was very prevalent as Myanmar like any other Southeast Asian society was male dominated where status between men and women is not equal and it also shares some 
cultural perspective on gender where women are put in a position often vulnerable to discrimination, repression, marginalization and even violence. Also the culture of group based discrimination in Myanmar is prevalent where Rohingya are seen as second class citizen by the Burmese particularly in Rakhine state. A Rohingya is considered even lower than a Rakhine woman as a result Rohingya women and girls are positioned to the lowest rank in social hierarchy. Moreover the military presence in the Rakhine region, created a perception that rape and sexual violence as acceptable and legitimate during the process of military operations which often tends to discriminate against women through dominant militarist cultural paradigms (Ventura, 2014).

\section{International Response}

In explaining the Rohingya crisis following areas can be examined such as nationality, statelessness and mass displacement which have implications on neighboring countries of Myanmar and finally the doctrine of responsibility to protect which concerns the international community. Even though the problem of Rohingya originates within Myanmar due to its historical and cultural indifferences, the effects are felt regionally and globally relevant to the efforts toward giving solutions should be directed and prioritized. The UN high commissioner has described the violence against Rohingya as the "textbook example of ethnic cleansing" which has resulted in religious extremism and mass displacement to different parts of world leading to what called as "humanitarian crisis" which is in enormous scale and scope. As a global issue this needs to be addressed and resolved by international community utmost possible (Kamarulzamanand and Beyrer, 2017).

The international community under the UN General Assembly in the World Summit outcome document agreed the doctrine of the responsibility to protect in 2005 (Hart,2017). It consisted of the main pillars Firstly; the state carries the primary responsibility to protect population from Genocide, war crimes, and ethnic cleansing. Secondly, the international community has the right to encourage and fulfill this responsibility and thirdly, has a clear responsibility to use appropriate diplomatic, humanitarian and other peaceful means in accordance with chapter iv and viii of the charter to help to protect from these crimes (Ibid).

The question of crimes against Rohingya is visible in various instances like UN Secretary General Antonio Gueterres described as one third of Rohingya population had to flee from its own country 
and the grievances that had been left to fester have escalated and destabilize the region. The crimes against humanity and spread that UN Human Rights Council had established a fact finding mission in Myanmar to investigate recent alleged rights violations by military and security forces and abuses. However this investigation has been under pinned by state Counselor of Myanmar about ongoing violence and destruction. It was highly contradicted by Human Rights Watch, which provided evidence of ongoing violence and burning of villages along with accounts of the survivor (Kamarulzamanand and Beyrer, 2017).

The UNHCR or Refugee Agency also largely helped in dealing with their identity except in records of UNHCR programmes, sanctioned by legality with transnational rights and extra territorial protection but officially they don't exist (Suan and Wong, 2012).With the large scale internal conflict and repression there has been condemnation from Bangladesh and the UN. Along with UN Human rights body reporting mass killings and gang rapes as policy of terror. Various reports of the UN Special Rapporteur gave details of systematic Human Rights Violations and lack of government response (Ibid).

The ASEAN platform also condemned Myanmar's action and also accused Myanmar for engaging in Genocide and creating regional instability calling for a review ASEAN membership. While ASEAN member states have breached the diplomatic and structural ties with Myanmar for practicing Human Rights Violations under its coverage (Ibid).

\section{Future Rights of Rohingya}

The isolation and suffering of the ordinary Rohingya can only be resolved unless they themselves as communities take sincere efforts to preserve their culture that they would lose. As Myanmar since its independence has been following a policy of national integration which might not accepted by westerns in fact, the problem of Arakanese Muslim refugee is seen as 'legacy of British colonial past'. Myanmar like any other sovereign country did not allow external interference in her internal affairs and does not tolerate any actions against its national security where Rohingya were apprehended for been involve in insurgent activities. Moreover the poor people were in the hands of different groups, the history of Rohingya does not consist of any consistent organized struggle. Rather it is a story of confused folk, played in hands of the British, communist and later got fractionalized among themselves (Azam, 2000). 
Rohingya under various conditions expect to return back to their country. The condition for repatriation includes:

- Giving their fundamental rights such as freedom of movement and education,

- Granting Citizenship,

- Compensating the houses and lands,

- Giving dignity and ensuring safety.

These are the basic Human Rights that are supposed to be entitled for being a human that are demanded by Rohingya. Hence it's violation of basic rights that state of Myanmar is practicing along with the host countries. It is the lack of safety and human dignity that makes majorly Rohingya reluctant to go back. Moreover the multi ethnic and religious environment makes this minority distrust and suspicious of majority religious fundamentalism and extremism. Most of the Rohingya reject to return without any justice has been found (Abiru, 2018).

They also claimed over their identity that the British government during their occupation of Myanmar there was presence of their community to clarify that they are not illegal Bengali immigrants. Deprival of the right to education in Myanmar especially higher education for Rohingya resulted in high rate of illiteracy which lacked their awareness about education and social activities especially among women (Abiru, 2018).

Rohingya as refugees are also facing a lot of discrimination especially in the host countries like Bangladesh where they are forced to hide their identity outside the camps. There are several checkpoints outside the camps by police and military to keep the Rohingya refugees inside. While the NGOs working in the host countries are largely biased towards them they considered Rohingya to be religious and conservative who followed some values and practices against common culture. Basic hygiene and importance of mental health care was to be inculcated them by changing their mindset. Rohingya women were often reluctant to work because of their tradition and belief however there were some instances, in which women participated in volunteering at women's training centres (Ibid).

Rohingya International Organisation which is working worldwide signed a joint statement for repatriation as a global network of Rohingya living in different parts of the world. The Rohingya 
International Organisations which include countries like Japan, Switzerland, Norway, Canada, UK, Myanmar, Malaysia etc are playing a significant role by providing remittances to families, contributing funds to refugees, lobbying the government and UN and also engaging in political activities. Some of the countries also made a plea in different Ministries to make policies on refugees (Ibid).

Moreover the Rohingya community was never fortunate to able to have leadership, nor could they mobilize international opinion in their favor. It should itself include in the process of decision making process and the various platforms which deals with their issue. They have to be included in any negotiations and determination about their future. While there is a belief that Rohingya in other democratic countries can better present their plight than Rohingyas in Myanmar itself (Ibid).

The existence of different religious groups and culture within a region is not unique in South and Southeast Asia there has been history of coexistence and mutual understanding as well as assimilation in grass root levels. Thus Rohingya dreaming of a homeland can have alternate by learn from history to integrate them with the multi ethnic tradition of Myanmar. It is the lack of good leadership, absence of proper education, provocation of fundamentalist forces that made Rohingya to unable to integrate with multi ethnic society. Hence leading to the suffering of the common people belonging to this particular Islamic faith in which mostly women and children have been victims (Azam, 2000).

Thus it can be stated that lack of human rights and consistent undermining of human rights of Rohingya as factor leading to conflict. As the conflict was born out of culture of discrimination which was fostered by the state authorities this resulted in intense tension and apprehension. Hence, demanding a structural democratic change internally by state by protecting their human rights which will engender structural change with equality leading to cultural change in the society (Jones, 2017). 


\section{References}

Abiru. Nozomi (2018), Exploring the human rights of the Rohingyas- A case study of Kutupalong refugee camp in Bangladesh, Norwegian University of Life Sciences

AlJazeera (2017), Myanmar: MajorEthnicgroups, Accessed on-16-3-2021, from https://www.aljazeera.com/indepth/interactive/2017/03/myanmar-major-ethnic-groups-live170309143208539.html

Azam J kousar (ed) (2001), Ethnicity, Identity and the State in South Asia, Osmania University, Hyderabad.

Brown. Gordon (2016), The Universal Declaration of Human rights in the $21^{\text {st }}$ century, Open book publishers, from www.jstor.org/stable/

Gamez Ramos Kimberly (2017), Examining the ASEAN Intergovernmental Commission on Human Rights (AICHR): The Case of Rohingya Crisis, Tilburg University

Hariharan VSM R. (May14, 2018), Ethnicity, Identity and Nationality: A Case Study of Rohingya problem, Chennai Centre for China Studies, Accessed on: 4-2-2021, from www.c3sindia.org/

Hart de Schuster sally (2017), "the Rohingya refugee crisis: a conflict amongst nations, Accessed on 23-4-2021, URL:- www.uninorte.edu.co

Human Rights Watch Report (2000), Malaysia/Burma living in limbo, from https://www.hrw.or/greport/2000/malyasia/maybr008-01.htm

Jones. William (2017), "Myanmar's rohingya: human rights abuses and systemic violence", Thailand, Accessed on 15-02-2021, from www.https://tci-thaijo.org

Kamarulzamanand. A, Chris. B (2017), "Ethnic cleansing in Myanmar: the Rohingya crisis and human rights", Accessed on 21-4-2021, from -www.thelancet.com

Karim, Abdul Dr. (June 2000), The Rohingyas: A Short Account of their History and Culture, Arakan Historical Society, Chittagong, Bangladesh

MOAS (2018), "The Human Trafficking of Rohingya", Accessed on 1-3-2021, from www.moas.eu 
Rahman Atikur km (July 2015), Ethno-political conflict: The Rohingya Vulnerability in Myanmar, Accessed on 5-3-2021, from https//www.researchgate.net/publication/ethno-political-conflict-theRohingya-vulnerability- in- Myanmar

Shetty Sunil Sakshi and Neranja Kassandra (2018), “From Encounter to Exodus: History of the Rohingya Muslims”, from www.researchgate.net/

Storai Yousuf (April 11, 2018), Systematic Ethnic Cleansing: The Case Study of Rohingya, Accessed on 28-3-2021, from Https//www.omicsonlineorg/open-accesss/systematic-cleansingthe-case-study-of-Rohingyas

Suan Pok Tan (2012), "Looking for a Life Rohingya Refugee Migration in the Post-Imperial Age”, Accessed on 21-4-2021

UN (11 May 2018), "For Rohingya refugees, imminent surge in births is traumatic legacy of sexual violence”, Migrants and Refugees, Accessed on 1- 3-2021, from Https://news.un.org

UNHCR (2018), “Culture, Context and Mental Health of Rohingya Refugees”, Accessed on 263-2021, from www.unhcr.org.

Ventura Alberto (2014), Identity, Conflict and Statelessness in South East Asia. Study Case: The Predicament of Rohingya, Accessed on 14-2-2021, from https://scholar.google.co.in

WIKICOMMONS_PALAUNG PEOPLE (2018), Ethnic Composition of Myanmar, accessed on 10-4-2021, from https://en.m.wikipedia.org

Yhome. k (JULY 2018), “Examining India's Stance on the Rohingya Crisis”, Issue no.247, ORF Issue Brief, Accessed on 12-4-2021, from www.orfonline.org / 